\title{
Hipernatremia dan Penatalaksanaanya
}

\section{Yuswanto Setyawan}

Bagian Ilmu Penyakit Dalam, Fakultas Kedokteran Universitas Ciputra, Surabaya, Indonesia Email: yuswanto_setyawan@yahoo.com

\begin{abstract}
Hypernatremia could be caused by loss of water (increased loss or decreased intake), and although rarely, due to over intake of natrium. Patients who are at risk of hypernatremia are those with disturbance of thirst or limited access of water. Several factors that could cause hypernatremia especially among geriatric patients are, as follows: change of thirst stimuli, decreased ability to concentrate urine, and decreased total body water. Clinical signs of hypernatremia are usually not specific, however, patients tend to become symptomatic if hypernatemia occurs acutely. Hypernatremia clinical signs are mostly neurological related to the severity and the change of serum sodium concentration. Complications of hypernatremia are inter alia shrinkage of brain tissue due to the movement of water from intracellular to extracellular fluid which results in injury of brain vessels, bleeding in the brain, and a variety of neurological signs due to brain involovement which could lead to death. Management of hypernatremia has to be carried out accurately and thoroughly because inaccurate or too-rapid correction could risk the occurrence of cerebral edema.
\end{abstract}

Keywords: hypernatremia, total body water

\begin{abstract}
Abstrak: Hipernatremia dapat disebabkan oleh kehilangan air (peningkatan kehilangan atau penurunan asupan) dan, walaupun jarang, karena kelebihan asupan natrium. Yang berisiko tinggi untuk hipernatremia ialah mereka dengan gangguan mekanisme rasa haus atau keterbatasan akses terhadap air. Berbagai faktor dapat menyebabkan hipernatremia terutama pada geriatri seperti perubahan rangsangan haus, berkurangnya kemampuan pemekatan urin, dan berkurangnya total body water. Gejala klinis hipernatremia biasanya tidak spesifik namun pasien cenderung menjadi simtomatik saat hipernatremia terjadi secara akut. Gejala hipernatremia terutama bersifat neurologik terkait dengan tingkat keparahan dan kecepatan perubahan konsentrasi natrium serum. Komplikasi hipernatremia ialah antara lain penyusutan otak akibat perpindahan cairan intrasel ke ekstrasel yang dapat merobek pembuluh darah otak, pendarahan otak, dan berbagai gejala neurologik akibat keterlibatan otak, yang dapat berakhir fatal. Penatalaksanaan hipernatremia perlu dilakukan dengan cermat karena penanganan yang tidak tepat atau koreksi yang terlalu cepat dapat berisiko terjadinya edema serebri.
\end{abstract}

Kata kunci: hipernatremia, total body water

\section{Pendahuluan}

Hipernatremia didefinisikan sebagai peningkatan kadar natrium lebih dari 145 $\mathrm{mmol} / \mathrm{L}$. Hal ini merupakan suatu kondisi hiperosmolar yang disebabkan oleh penurunan total body water (TBW) relatif terhadap kandungan elektrolit. Hipernatremia dapat disebabkan oleh kehilangan air (peningkatan kehilangan atau penurunan asupan) atau, walaupun jarang, karena kele- bihan asupan natrium. Pasien yang berisiko tinggi untuk hipernatremia ialah termasuk mereka dengan gangguan mekanisme rasa haus atau keterbatasan akses terhadap air (misalnya: terdapat perubahan status mental, sedang diintubasi, bayi, dan pasien lansia). Hipernatremia pada orang dewasa hampir selalu terjadi karena kehilangan air daripada karena asupan natrium yang berlebihan. ${ }^{1,2}$ 
Insidensi hipernatremia pada pasien rawat inap berkisar 3-5 per 100.000 individu di seluruh dunia sedangkan prevalensi hipernatremia pada pasien kondisi kritis sekitar 9-26 per 100.000 individu, dan umumnya mengenai lanjut usia. Selain itu tidak terdapat perbedaan prevalensi hipernatremia berdasarkan ras dan jenis kelamin. ${ }^{3}$ Imai et $\mathrm{al}^{4}$ melaporkan bahwa prevalensi hipernatremia secara bermakna lebih tinggi pada usia lanjut dibandingkan dewasa $(1,0 \%$ vs $0,1 \%$; $<<0,001)$. Demikian pula prevalensi hipernatremia sedang sampai \berat secara bermakna lebih tinggi pada lanjut usia dibandingkan dewasa pada semua iklim.

Gejala klinis hipernatremia biasanya tidak spesifik dan pasien cenderung menjadi simtomatik saat hipernatremia terjadi secara akut (biasanya <48 jam). Penilaian hipernatremia akut atau kronis bergantung terhadap gejala yang timbul. Hipernatremia akut terjadi ketika timbul gejala berat, pengobatan segera diperlukan dan harus mendahului evaluasi diagnostik. Sebaliknya, hipernatremia kronik ialah ketika sedikit gejala yang timbul, penyebab yang mendasari harus diidentifikasi dan serum natrium harus dikoreksi secara bertahap. Komplikasi hipernatremia ialah antara lain penyusutan otak akibat perpindahan cairan intrasel ke ekstrasel yang dapat merobek pembuluh darah otak, pendarahan otak, kejang, kelumpuhan, dan ensefalopati, dan bila berkepanjangan, dapat menyebabkan edema serebral, yang dapat menyebabkan koma, kejang, dan kematian. Jika koreksi natrium pada hipernatremia kronis dilakukan terlalu cepat, maka dapat berisiko terjadi edema serebri. ${ }^{5}$

Hipernatremia lebih jarang terjadi dibandingkan dengan hiponatremia dan gejala yang menonjol biasanya hanya pada peningkatan konsentrasi natrium plasma yang cepat dan besar diatas 158 sampai 160 $\mathrm{mmol} / \mathrm{L}$. Satu alasan untuk hal ini ialah bahwa hipernatremia menimbulkan rasa haus yang luar biasa yang melindungi tubuh dari peningkatan natrium dalam plasma dan cairan ekstrasel. Hipernatremia yang berat dapat terjadi pada pasien yang dengan lesi hipotalamik yang mengganggu sensasi rasa haus, bayi yang tidak dapat langsung mendapat minuman, atau pada lanjut usia yang mengalami gangguan mental. ${ }^{6}$

Respon fisiologik hipernatremia ialah meningkatnya pengeluaran antidiuretic hormone (ADH) dari hipotalamus sehingga ekskresi urin berkurang sehingga osmolelitas urin meningkat. Manusia dalam keadaan normal tidak akan pernah mengalami hipernatremia, karena respon haus yang timbul akan direspon dengan asupan air yang meningkat sehingga tidak terjadi hipernatremia. Hipernatremia terjadi bila kekurangan air tidak diatasi dengan baik misalnya pada lanjut usia dan diabetes insipidus (volume urin dapat $>10 \mathrm{~L}$ ). Dalam keadaan hipotalamus yang normal serta fungsi ginjal normal, hipernatremia akan menyebabkan osmolalitas urin menjadi lebih dari $700-800 \mathrm{mosmol} / \mathrm{kg}^{7}$

Dalam kaitan dengan hipernatremia, harus dibedakan antara hipovolemia dengan dehidrasi. Hipovolemia adalah keluarnya air bersama natrium secara seimbang (isotonik) dari cairan ekstrasel tanpa perubahan kadar natrium plasma. Dehidrasi adalah keluarnya air tanpa natrium (cairan hipotonik) dari cairan ekstrasel yang mengakibatkan timbulnya hipernatremia. Dengan kata lain, hipovolemia disertai dengan normonatremia sedangkan dehidrasi disertai dengan hipernatremia. $^{7}$

Mengingat bahwa baik hipernatremia akut maupun hipernatremia kronis memerlukan penatalaksanaan yang segera dan tepat, serta komplikasinya yang dapat berakibat fatal maka penulis terdorong untuk membahas mengenai hipernatremia dan penatalaksanaannya agar dapat memberikan wawasan yang lebih luas bagi para tenaga medis untuk lebih mewaspadai kejadian hipernatremia terutama pada pasien geriatri.

\section{Fisiologi Natrium}

Natrium adalah kation terbanyak dalam cairan ekstrasel, jumlahnya bisa mencapai $60 \mathrm{mEq}$ per kilogram berat badan, dan sebagian kecil (sekitar 10-14 mEq/L) berada dalam cairan intrasel. Lebih dari $90 \%$ tekanan osmotik di cairan ekstrasel ditentukan 
oleh garam yang mengandung natrium, khususnya dalam bentuk natrium klorida $(\mathrm{NaCl})$ dan natrium bikarbonat $(\mathrm{NaHCO} 3)$ sehingga perubahan tekanan osmotik pada cairan ekstrasel menggambarkan perubahan konsentrasi natrium. Perbedaan kadar natrium intravaskuler dan interstitial disebabkan oleh keseimbangan Gibbs-Donnan, sedangkan perbedaan kadar natrium dalam cairan ekstrasel dan intrasel disebabkan oleh adanya transpor aktif dari natrium keluar sel yang bertukar dengan masuknya kalium ke dalam sel (pompa $\mathrm{Na}+\mathrm{K}+$ ). Jumlah natrium dalam tubuh merupakan gambaran keseimbangan antara natrium yang masuk dan yang dikeluarkan. Pemasukan natrium yang berasal dari diet melalui epitel mukosa saluran cerna dengan proses difusi dan pengeluarannya melalui ginjal atau saluran cerna atau keringat di kulit. Pemasukan dan pengeluaran natrium perhari mencapai 48$144 \mathrm{mEq}^{8}$

Jumlah natrium yang keluar dari saluran cerna dan kulit kurang dari $10 \%$. Cairan yang berisi konsentrasi natrium yang berada pada saluran cerna bagian atas hampir mendekati cairan ekstrasel, namun natrium direabsorpsi sebagai cairan pada saluran cerna bagian bawah. Oleh karena itu konsentrasi natrium pada feses hanya mencapai $40 \mathrm{mEq} / \mathrm{L}$. Keringat merupakan cairan hipotonik yang mengandung natrium dan klorida. Rerata kandungan natrium pada cairan keringat individu normal ialah 50 $\mathrm{mEq} / \mathrm{L}$. Jumlah pengeluaran keringat akan meningkat sebanding dengan lamanya periode terpapar pada lingkungan yang panas, latihan fisik, dan demam. Ekskresi natrium terutama dilakukan oleh ginjal. Pengaturan eksresi ini dilakukan untuk mempertahankan homeostasis natrium, yang sangat diperlukan untuk mempertahankan volume cairan tubuh. ${ }^{8}$

Natrium difiltrasi bebas di glomerulus, direabsorpsi secara aktif $60-65 \%$ di tubulus proksimal bersama dengan $\mathrm{H}_{2} \mathrm{O}$ dan klorida yang direabsorpsi secara pasif, sisanya direabsorpsi di lengkung Henle (25-30\%), tubulus distal (5\%), dan duktus koligentes (4\%). Sekresi natrium di urin kurang dari $1 \%$. Aldosteron menstimulasi tubulus distal untuk mereabsorpsi natrium bersama air secara pasif dan menyekresi kalium pada sistem renin-angiotensin-aldosteron (RAAS) untuk mempertahankan elektroneutralitas. ${ }^{8}$

\section{Etiologi Hipernatremia}

Peningkatan konsentrasi natrium plasma, yang juga menyebabkan peningkatan osmolaritas, dapat disebabkan oleh kehilangan air dan cairan ekstrasel, yang memekatkan ion natrium, atau karena kelebihan natrium dalam cairan ekstrasel Kehilangan pimer air dari cairan ekstrasel akan menyebabkan terjadinya hipernatremia-dehidrasi. Kondisi ini dapat terjadi akibat ketidakmampuan untuk menyekresi hormon ADH yang dibutuhkan oleh ginjal untuk menahan air. Akibat tidak adanya ADH, ginjal mengeluarkan urin encer dalam jumlah yang sangat besar (kelainan ini disebut sebagai diabetes insipidus), yang menyebabkan timbulnya dehidrasi dan peningkatan konsentrasi natrium klorida dalam cairan ekstrasel. Pada jenis-jenis penyakit ginjal tertentu, ginjal tidak berespon terhadap ADH, yang juga menyebabkan jenis kelainan yang disebut diabetes insipidus nefrogenik. Penyebab hipernatremia yang lebih umum akibat penurunan volume cairan ekstrasel ialah dehidrasi akibat asupan air yang lebih sedikit daripada pengeluarannya, seperti halnya pada keadaan berkeringat selama aktivitas berat yang berkepanjangan. ${ }^{6}$

Hipernatremia juga dapat terjadi akibat penambahan natrium klorida yang berlebihan pada cairan ekstrasel. Hal ini sering terjadi pada hipernatremia-hiperhidrasi, karena kelebihan natrium klorida ekstrasel, biasanya juga berhubungan dengan beberapa derajat retensi air oleh ginjal. Sebagai contoh, sekresi berlebihan dari hormon aldosteron yang meretensi natrium dapat menyebabkan hipernatremia ringan dan overhidrasi. Alasan bahwa hipernatremia ini tidak lebih berat ialah bahwa peningkatan sekresi aldosteron menyebabkan ginjal mereabsorbsi air dan natrium dalam jumlah yang lebih besar. ${ }^{6}$

Secara umum, penyebab hipernatremia dapat dibagi menjadi penyebab primer yang disebabkan oleh keseimbangan air negatif 
(karena diuresis air atau zat terlarut) dan penyebab primer yang disebabkan oleh keseimbangan natrium positif, atau kombinasi keduanya. ${ }^{5}$

Hipernatremia terjadi bila terdapat defisit cairan tubuh akibat ekskresi air melebihi ekskresi natrium, misalnya pada pengeluaran air melalui insensible water loss (keringat); diare osmotik akibat pemberian laktulose atau sorbitol; diabetes insipidus sentral maupun nefrogenik; diuresis asmotik akibat glukosa atau manitol; gangguan pusat rasa haus di hipotalamus akibat tumor atau gangguan vaskular sehingga pengeluaran air melalui insensible water loss (keringat) tidak direspon dengan keinginan minum. Hipernatremia dapat juga disebabkan oleh penambahan natrium yang melebihi jumlah cairan dalam tubuh, missalnya koreksi bikarbonat berlebihan pada asidosis metabolik. Pada keadaan ini tidak terjadi deplesi volume sehingga natrium yang berlebihan akan diekskresikan dalam urin menyebabkan kadar $\mathrm{Na}$ dalam urin lebih dari $100 \mathrm{meq} / \mathrm{L} .{ }^{8}$ Penyebab lain dari hipernatremia ialah masuknya air tanpa elektrolit ke dalam sel. Misalnya pada latihan olahraga yang berat, asam laktat dalam sel meningkat sehingga osmolalitas sel juga meningkat dan air dari ekstrasel akan masuk ke intrasel. Biasanya kadar natrium akan kembali normal dalam waktu 5-15 menit setelah istirahat. ${ }^{7}$ Penyebab tersering hipernatremia ialah diuresis osmotik (misal hiperglikemia), makanan enteral protein tinggi, diabetes insipidus (sentral, nefrogenik, gestasional), menyusui, dan aldosteronisme primer. ${ }^{5}$

\section{Klasifikasi Hipernatremia}

Hipernatremia dapat diklasifikasikan sebagai hipernatremia hipovolemia, euvolemia, dan hipervolemia. Pada hipernatremia hipovolemia terdapat jumlah natrium tubuh rendah dengan kehilangan air lebih banyak daripada kehilangan natrium. Pasien mengalami penurunan volume cairan ekstrasel, defisit air bebas, dan elektrolit (kadar natrium dan kalium dalam tubuh rendah). Hipovolemia merupakan keadaan yang lebih mengancam jiwa daripada hiper- tonik. Resusitasi cairan dengan normal salin ialah langkah pertama dalam terapi. Kehilangan cairan hipotonik renal dapat terjadi akibat penggunaan obat diuretik (loop diuretic dan tiazid), diuresis osmotik (hiperglikemia, manitol, urea), garam ginjal, nekrosis tubular akut fase diuresis, kehilangan cairan hipotonik non-renal melalui saluran cerna (muntah, diare, laktulosa, katarsis, nasogastric suction, drainase cairan gastrointestinal, dan fistula) atau melalui kulit (berkeringat akibat olahraga ekstrim, lari maraton, serta luka bakar). ${ }^{9}$

Pada hipernatremia, euvolemia terdapat jumlah natrium tubuh normal tetapi terjadi kehilangan air. Pasien memiliki volume cairan ekstrasel normal dengan kadar natrium dan kalium total tubuh normal. Keadaan ini paling sering terjadi pada beberapa keadaan, seperti gangguan asupan dan kurangnya akses terhadap air dikombinasikan dengan peningkatan insensible water loss (pernapasan atau kulit), kehilangan air ginjal pada penyakit ginjal primer (uropati obstruktif, displasia ginjal, penyakit kista meduler, refluks nefropati, penyakit polikistik) atau penyakit sistemik dengan keterlibatan ginjal (penyakit sel sabit, amiloidosis), obat-obatan (amfoterisin, fenitoin, litium, aminoglikosida, metoksifluran), serta ketidakmampuan ginjal untuk memekatkan urin (diabetes insipidus sentral atau nefrogenik). ${ }^{9}$

Pada hipernatremia hipervolemia terdapat jumlah natrium tubuh yang meningkat. Pasien memiliki kelebihan volume cairan ekstrasel dengan kadar natrium total tubuh yang tinggi, kelebihan mineralokortikoid (sindrom Cushing, hiperaldosteronisme primer), namun sebagian besar terjadi karena penyebab iatrogenik akibat pemberian larutan elektrolit hipertonik (larutan natrium bikarbonat, atau pada hemodialisis). ${ }^{9}$

\section{Manifestasi Klinis Hipernatremia}

Gejala klinis hipernatremia biasanya tidak spesifik. Gejala klinis timbul pada keadaan peningkatan natrium plasma secara akut diatas $158 \mathrm{meq} / \mathrm{L}$. Gejala yang ditimbulkan akibat mengecilnya volume otak 
karena air keluar dari dalam sel. Pengecilan volume ini menimbulkan robekan pada vena menyebabkan perdarahan lokal di otak dan perdarahan subaraknoid. Gejala dimulai dari letargi, lemas, twitching, kejang dan akhirnya koma. Kenaikan akut diatas $180 \mathrm{meq} / \mathrm{L}$ dapat menimbulkan kematian. ${ }^{7,10}$

Gambaran klinis hipernatremia sebagian besar merupakan konsekuensi penyusutan otak, termasuk letargi, mengantuk, dan perubahan status mental, yang mengarah pada kejang, koma, dan kematian jika tidak ditangani dengan segera. ${ }^{11}$

Pada pasien dengan hipernatremia berat, osmolalitas urin secara nyata lebih tinggi daripada pada pasien dengan hiponatremia, yang menunjukkan bahwa dehidrasi memainkan peran utama. Indikator lain ialah tingkat kreatinin serum yang lebih tinggi pada pasien dengan hipernatremia berat pada keadaan pre-renal akibat dehidrasi. Sekitar $11 \%$ pasien dengan hipernatremia berat menggunakan diuretik loop, yang dapat menyebabkan konsentrasi urin lebih rendah dan peningkatan natrium serum. $^{12}$

\section{Diagnosis Hipernatremia}

Penyebab hipernatremia didapatkan dari anamnesis dan pemeriksaan fisik, dan biasanya diakibatkan kehilangan air (missalnya, kehilangan air di saluran cerna, akses terbatas terhadap air) atau kelebihan natrium. Pasien sering tanpa gejala tetapi dapat muncul gejala iritabilitas, mual, kelemahan, perubahan status mental, atau koma. Kehilangan air dapat berupa kehilangan air murni (misalnya, diabetes insipidus) atau kehilangan cairan hipotonik (misalnya, kehilangan cairan melalui ginjal, saluran cerna, atau kulit). Kenaikan natrium biasanya karena iatrogenik akibat infus larutan hipertonik. ${ }^{13}$

\section{Tatalaksana Hipernatremia}

Langkah pertama yang dilakukan ialah menetapkan etiologi hipernatremia. Setelah etiologi ditetapkan, pada langkah berikut dicoba menurunkan kadar natrium dalam plasma ke arah normal. Pada diabetes insipidus, sasaran pengobatan ialah mengu- rangi volume urin. Bila penyebabnya ialah asupan natrium berlebihan, pemberian natrium dihentikan. ${ }^{7}$

Pengobatan dilakukan dengan koreksi cairan berdasarkan penghitungan jumlah defisit cairan. Koreksi hipernatremia dapat dilakukan dengan memberikan larutan natrium klorida yang hipo-osmotik atau dengan larutan dekstrosa. Pemberian larutan tersebut pada pasien dengan peningkatan kadar natrium kronis harus dengan kecepatan lambat. Alasannya ialah hipernatremia juga meningkatkan aktivitas mekanisme pertahanan yang melindungi sel dari perubahan volume. Mekanisme pertahanan ini ialah sebaliknya dari yang terjadi pada hiponatremia, dan terdiri atas mekanisme yang meningkatkan kadar natrium intrasel dan zat terlarut lainnya. ${ }^{6}$

Pengurangan maksimum konsentrasi natrium serum yang disarankan ialah 12 mmol/L dalam 24 jam. ${ }^{14}$ Perhitungan defisit tubuh air total (TBW) ialah Defisit air = TBW saat ini $\mathrm{x}$ (serum $[\mathrm{Na}] / 140$ - 1). Untuk total body water (TBW) saat ini dipergunakan patokan sebagai berikut, yaitu pria muda: $60 \%$ berat badan tanpa lemak; wanita muda: $50 \%$ berat badan tanpa lemak; pria lansia: $50 \%$ berat badan tanpa lemak; dan wanita lansia: $45 \%$ berat badan tanpa lemak. Formula ini memberikan perkiraan volume cairan tambahan yang diperlukan untuk memperbaiki konsentrasi natrium serum hingga 140mmol/L. ${ }^{15}$

Sebagai rekomendasi untuk koreksi hipernatremia, dilakukan hal-hal sebagai berikut: ${ }^{6}$ Pada hipernatremia akut atau sangat simtomatik, pengobatan segera dengan cairan hipotonik harus dimulai, terlepas dari penyebab yang mendasari. Bila seorang pasien dengan hipernatremia memiliki hipotensi, pemberian cairan isotonik harus dimulai. Pada hipernatremia kronis, koreksi cepat harus dihindari untuk mencegah edema serebral dan perawatan diarahkan ke penyebab yang mendasari. Untuk semua penyebab hipernatremia, angka koreksi terbatas hingga $8 \mathrm{mmol} / \mathrm{L}$ dalam 24 jam pertama dan $18 \mathrm{mmol} / \mathrm{l}$ dalam 48 jam pertama. Hipernatremia akut dapat dikoreksi lebih cepat pada awalnya (1-2 $\mathrm{mmol} / \mathrm{L} / \mathrm{jam})$; 
kenaikan $5 \mathrm{mmol} / \mathrm{L}$ biasanya cukup untuk memperbaiki gejala. ${ }^{15}$

Hemodialisis juga telah digunakan untuk pengobatan hipernatremia akut ketika pengobatan konvensional gagal dilakukan. Hemodialisis memiliki kelebihan dibandingkan metode konvensional karena memungkinkan pengeluaran cepat kelebihan natrium dan penggantian cairan. Selain itu, dialisis memungkinkan kontrol cairan dan elektrolit yang lebih baik dalam situasi yang rumit pada pasien dengan gangguan kardiopulmonar atau gangguan ginjal. ${ }^{15}$

\section{Komplikasi Hipernatremia}

Hipernatremia-dehidrasi berat dapat menyebabkan penyusutan otak akibat adanya perpindahan cairan intrasel ke ekstrasel, yang dapat merobek pembuluh darah otak, menyebabkan pendarahan otak, kejang, kelumpuhan, dan ensefalopati. Pada pasien dengan hipernatremia yang berkepanjangan, rehidrasi cepat dengan cairan hipotonik dapat menyebabkan edema serebral, yang dapat menyebabkan koma, kejang, dan kematian. Hipernatremia akut $<24$ jam dapat menyebabkan perdarahan subdural. Kongesti vena dapat menyebabkan trombosis sinus vena intrakranial. Peregangan arterial dapat menyebabkan perdarahan subkortikal dan infark serebral. Kejang mungkin dapat terjadi. Hipernatremia kronis dengan durasi lebih dari dua hari dikaitkan dengan peningkatan mortalitas terutama jika dikoreksi terlalu cepat, edema otak dan sekuale neurologik yang terkait dapat terjadi. ${ }^{9,10}$

Hipernatremia berat dapat menyebabkan angka mortalitas pada pasien lanjut usia sebesar 40-70\%. Dalam prakteknya, seringkali sulit untuk memisahkan kontribusi hipernatremia dengan mortalitas dari penyakit yang mendasarinya. Tingkat kesadaran merupakan indikator prognosis terbaik yang terkait dengan mortalitas pada lansia. Studi pada pasien sakit kritis di ICU menunjukkan bahwa hipernatremia merupakan faktor risiko independen untuk mortalitas. Sebagian besar kasus tampaknya timbul setelah masuk ke ICU dan, oleh karena itu, mungkin setidaknya sebagian berasal dari iatrogenik. ${ }^{16}$

\section{Simpulan}

Gejala hipernatremia terutama bersifat neurologik terkait dengan tingkat keparahan dan kecepatan perubahan konsentrasi natrium serum. Komplikasi hipernatremia ialah antara lain penyusutan otak akibat perpindahan cairan intrasel ke ekstrasel yang dapat merobek pembuluh darah otak, serta berbagai manifestasi neurologik kelainan otak, yang dapat berakhir dengan kematian. Penatalaksanaan hipernatremia perlu dilakukan dengan cermat karena penanganan yang tidak tepat atau koreksi yang terlalu cepat dapat berisiko terjadinya edema serebri.

\section{Konflik Kepentingan}

Penulis menyatakan tidak terdapat konflik kepentingan dalam studi ini.

\section{DAFTAR PUSTAKA}

1. Lukitsch I. Hypernatremia. 2021. Available from: https://emedicine.medscape.com/ article/241094-overview

2. Sam R, Feizi I. Understanding hipernatremia. Am J Nephrol. 2012;36(1):97-104.

3. Search WikiDoc. Hypernatremia epidemiology and demographics. Available from:https://www.wikidoc.org/ index. php/Hypernatremia_epidemiology_an d_demographics.

4. Imai N, Sumi H, Shibagaki Y. Impact of age on the seasonal prevalence of hypernatremia in the emergency department: a single-center study. Int $\mathbf{J}$ Emerg Med. 2019;12:29

5. Hoorn EJ, Tuut MK, Hoorntje SJ, van Saase JLMC, Zietse R, Geers AB. Dutch guideline for the management of electrolyte disorders. Neth J Med. 2013; 71(3):153-65.

6. Guyton AC, Hall JE. Buku Ajar Fisiologi Kedokteran (12th ed). Jakarta: EGC, 2014.

7. Siregar P. Gangguan keseimbangan air dan elektrolit. In: Sudoyo AW, Setiyohadi B, Alwi I, Simadibrata MS, Setiati, editors. Buku Ajar Ilmu Penyakit Dalam (6th ed). Jakarta: Interna Publishing, 2014.

8. Yaswir R, Ferawati I. Fisiologi dan gangguan keseimbangan natrium, kalium dan klorida serta pemeriksaan laboratorium. 
Journal Kesehatan Andalas. 2012;1(2): 80-4.

9. Al-Shahraban S, Butrus S. Guidelines for the management of hypernatraemia. Available fromL https://www.kbms.org/ Uploads/Guideline\%20management/G uideline, $\% 20$ Management $\% 20 \mathrm{of} \% 20 \mathrm{H}$ ipernatremia.pdf

10. Semenovskaya Z. Hipernatremia in emergency medicine: background, pathophysiology, epidemiology. 2018. Available from https://emedicine.medscape. com/article/766683-overview

11. Masters P. Southern Derbyshire shared care, pathology guidelines, hypernatraemia in adults. 2015. Available from: http:// www.derbyhospitals.nhs.uk/easysitewe b/getresource.axd?assetid=12188\&type $=0$ \&servicetype $=1$

12. Arampatzis S, Frauchiger B, Fielder G-M, Leichtle AB, Buhl D, Schwarz C, et al. Characteristics, symptoms, and outcome of severe dysnatremias present on hospital admission. Am J Med. 2012; 125(11):1125.e1-e7.

13. Seay N, Lehrich RW, Greenberg A. Diagnosis and management of disorders of body toxicity-hyponatremia and hypernatremia: Core Curriculum 2020. Am J Kidney Dis. 2019;75(2):272-86.

14. Liamis G, Filippatos TD, Elisaf MS. Evaluation and treatment of hypernatremia: a practical guide for physicians. Postgrad Med. 2016;128(3):299-306.

15. Nur Saima, Khan Y, Nur Saadia, Boroujerdi H. Hypernatremia: Correction rate and hemodialysis. Case Rep Med. 2014; 2014:1-4.

16. Harding M. Hypernatraemia. 2016. Available from:https://patient.info/doctor/hyperna traemia\#ref-5 